\title{
KESIAPAN GURU SD DALAM PELAKSANAAN PEMBELAJARAN TEMATIK- INTEGRATIF PADA KURIKULUM 2013 DI DIY
}

\section{THE STUDY ON THE ELEMANTARY SCHOOL TEACHERS READINESS IN IMPLEMENTING THEMATIC-INTEGRATIVE TEACHING AND LEARNING IN CURRICULUM 2013, YOGYAKARTA}

\author{
Muhammad Nur Wangid, Ali Mustadi, Vera Yuli Erviana, Slamet Arifin \\ Universitas Negeri Yogyakarta, Universitas Negeri Yogyakarta, IKIP PGRI Wates, SDN Tanjungtirto \\ nurwangid2003@yahoo.com, ali_mustadi@uny.ac.id,vhera_uny@yahoo.co.id, \\ masarifinspd@gmail.com
}

\begin{abstract}
Abstrak
Penelitian ini bertujuan untuk mendeskripsikan kesiapan guru Sekolah Dasar (SD) dalam menerapkan Kurikulum 2013 khususnya dalam pembelajaran tematik-integratif di Daerah Istimewa Yogyakarta (DIY). Jenis penelitian yang digunakan yaitu penelitian survei. Populasi penelitian adalah guru kelas I dan IV yang terdapat di wilayah DIY. Jumlah sampel yang diambil dalam penelitian ini adalah sebanyak 182 guru SD yang berasal dari 49 SD negeri dan 15 SD swasta yang dijadikan pilot project berdasarkan data dari Kemdikbud DIY. Hasil penelitan menunjukkan bahwa persentase kesiapan guru SD di DIY dalam melaksanakan pembelajaran tematik-integratif pada Kurikulum 2013 sebesar 75,85\% (siap), dilihat dari aspek kesiapan yaitu aspek Behavioral Readiness diperoleh persentase sebesar 80\% (sangat siap), aspek Emotive-Ettitudinal sebesar 78,39\% (sangat siap) dan aspek Cognitive Readiness sebesar 71,18\% (siap). Sedangkan kesiapan guru SD di setiap kabupaten diperoleh hasil persentase sebagai berikut: Sleman 76,13\% (sangat siap), Yogyakarta 78,72\% (sangat siap), Bantul 73,16\% (siap), Gunungkidul 75,54\% (siap), dan Kulon Progo 75,42\% (siap).
\end{abstract}

Kata Kunci: Kesiapan guru, tematik-integratif, kurikulum 2013

\begin{abstract}
This study aims to describe the readiness of elementary school teachers in implementing curriculum 2013, based on thematic-integrative learning in Yogyakarta Province. This is a survey study. The research population were elemantary school teachers of class I and IV in DIY. The research sample consisted of 289 elemantary school teachers from 49 public schools and 15 private elementary schools which used as pilot project based on the data from Kemdikbud. The result shows that the percentage of elementary school teachers readiness in to implementing thematic-integrative learning is $75.85 \%$ (ready): the precentage of readiness behavioral aspects is $80 \%$ (well prepared), emotive ettitudinal aspect is $78.39 \%$ (well prepared) and cognitive readiness aspects is $71.18 \%$ (ready). While the readiness of elementary school teachers in each district are follows: Sleman $76.13 \%$ in the category of (well prepared), Yogyakarta $78.72 \%$ in the category of (well prepared), Bantul $73.16 \%$ in the category of (ready), Gunungkidul $75.54 \%$ in the category of (prepared), and Kulon Progo $75.42 \%$ in the category of (ready).
\end{abstract}

Keywords: Elemantary school teachers readiness, thematic-integrative, kurikulum 2013 


\section{Pendahuluan}

Perkembangan ilmu pengetahuan dan teknologi telah membawa perubahan dihampir semua aspek kehidupan manusia dimana berbagai permasalahan hanya dapat dipecahkan dengan upaya penguasaan dan peningkatan ilmu pengetahuan dan teknologi. Selain manfaat bagi kehidupan manusia disatu sisi perubahan tersebut juga telah membawa manusia ke dalam era persaingan global yang semakin ketat. Agar mampu berperan dalam persaingan global, maka sebagai bangsa kita perlu terus mengembangkan dan meningkatkan kualitas sumber daya manusianya. Oleh karena itu, peningkatan kualitas sumber daya manusia merupakan kenyataan yang harus dilakukan secara terencana, terarah, intensif, efektif dan efisien dalam proses pembangunan, kalau tidak ingin bangsa ini kalah bersaing dalam menjalani era globalisasi tersebut.

Irianto. (2011, p.5) menyatakan bahwa hendaknya pendidikan mampu melahirkan lapisan masyarakat terdidik dan menjadi kekuatan yang merekatkan unit-unit sosial di dalam masyarakat. Upaya pembaharuan dan peningkatan kualitas pendidikan pemerintah memastikan diterapkannya kurikulum baru yaitu Kurikulum 2013 yang merupakan penyempurnaan dari kurikulum KTSP yang telah berjalan sebelumnya. Seiring dengan kepastian pemerintah terkait dengan pengembangan kurikulum dari KTSP menuju Kurikulum 2013 memunculkan sebuah tantangan baru bagi guru. Konsep Kurikulum 2013 ini menuntut guru agar menerapkan pembelajaran berbasis tematik-integratif. Pembelajaran tematik bukanlah hal yang baru bagi para guru SD di negara kita ini.Sejatinya model pembelajaran tematik telah diperkenalkan pula pada kurikulum yang sebelumnya yaitu kurikulum KTSP. Pada kurikulum KTSP pembelajaran tematik sudah diterapkan pada kelas I, II, dan III SD. Walau sudah diterapkan di kelas I, II, dan III pada saat kurikulum KTSP berjalan, pelaksanaan pembelajaran tematik dirasa masih sangat kurang efektif.

Perubahan kurikulum KTSP menjadi Kurikulum 2013 telah disiapkan oleh pemerintah. Berbagai upaya telah dilakukan oleh pemerintah sebelum kurikulum yang baru ini benarbenar diterapkan pada tahun ajaran baru 2013. Kegiatan uji publik dilakukan untuk memperoleh masukan dari berbagai lapisan masyarakat. Seminar dan pelatihan-pelatihan bagi guru dalam persiapan menghadapi Kurikulum 2013 ini juga telah dirancang sedemikian rupa. Halhal tersebut dilakukan oleh pemerintah tentunya bertujuan agar ketika Kurikulum 2013 ini dilaksanakan tidak memiliki kendala dan halangan yang berarti bagi para guru sebagai pelaksana di lapangan.

Pengalaman dari kebijakan-kebijakan sebelumnya mengenai kurikulum banyak pihak yang mengeluhkan pergantian kurikulum. Pergantian kurikulum terjadi begitu cepat sehingga membuat para guru kesulitan dalam melaksanakan apa yang dimaksudkan dalam kurikulum tersebut dalam kegiatan di lapangan. Sejatinya perubahan kurikulum memang sudah ditentukan dan disesuaikan dengan tuntutan dan kebutuhan yang ada, namun sosialisasi yang kurang dan persiapan yang kurang matang biasanya menjadi penghambat dan tantangan dalam pelaksanaannya di lapangan. Tidak sedikit pihalpihak yang menyuarakan bahwa setiap ganti menteri kurikulum ikut berganti.

Sebelum Kurikulum 2013 ini dipastikan diterapkan sudah muncul berbagai isu baik yang pro dan kontra. Argumen-argumen yang bersifat kontra muncul bukan karena tidak punya alasan. Persiapan Kurikulum 2013 yang dinilai terlalu mepet dan tergesa-gesa menjadi sebuah hal yang sering menjadikan keraguan akan keberhasilan pelaksanaan Kurikulum 2013 ini. Seperti yang dinyatakan oleh ketua Persatuan Guru Republik Indonesia (PGRI) Daerah Istimewa Yogyakarta (DIY) Zainal Fanani, menganggap pelaksanaan Kurikulum 2013 terlalu tergesa-gesa. "Pelaksanaan Kurikulum 2013 tergesa-gesa dan dipaksakan pada tahun ajaran baru 2013 ini nanti hasilnya tidak sesuai dengan yang diharapkan dan hanya kulitnya saja" (Maddox, dkk: 2013). Maka dari itu sosialisasi dan pelatihan Kurikulum 2013 terhadap guru-guru sebagai pelaksana di lapangan menjadi sebuah hal yang penting dan wajib hukumnya. Mengingat, guru sebagai motor utama penentu keberhasilan penerapan Kurikulum 2013 ini di lapangan. Kesiapan dan pemahaman guru terhadap ruh Kurikulum 2013 harus dimiliki oleh semua guru. Pemahaman guru terhadap ruh Kurikulum 2013 inilah yang akan menjadikan guru bisa melakukan tindakan yang sesuai dengan maksud dan tujuan yang ada dalam Kurikulum 2013. Dengan demikian kesiapan dan pemahaman guru terhadap Kurikulum 2013 ini menjadi hal yang sangat menentukan dalam keberhasilan dan pencapaian tujuan dari Kurikulum 2013. 
Berdasarkan latar belakang masalah yang diuraikan tersebut, rumusan masalah yang diambil yaitu tentang kesiapan guru SD di DIY terhadap penerapan Kurikulum 2013. Berdasarkan rumusan masalah tersebut, maka tujuan yng ingin dicapai pada penelitian ini adalah mendeskripsikan kesiapan guru SD di DIY terhadap penerapan Kurikulum 2013.

Kesiapan berasal dari kata "siap" mendapat awalan ke- dan akhiran -an. Dalam Kamus Besar Bahasa Indonesia (2003), menjelaskan kesiapan adalah suatu keadaan bersiapsiap untuk mempersiapkan sesuatu. Thorndike (Bower, 2000, p.27), menyatakan kesiapan dalam hukum kesiapan (law of readiness) sebagai berikut.

Thordike recognized several forms of readines; if a strong desire for an action sequence is aroused, then the smooth carrying out of that sequence is satisfying; if that action sequence is thwarted or blocked from completion, then such blocking is annoying; if an action is fatigued (tired out) or satiated, then forcing a further repetition of act is annoying.

Artinya bahwa menurut Thorndike ada beberapa kondisi yang akan muncul pada hukum kesiapan ini, diantaranya: (a) jika individu siap untuk bertindak dan mau melakukannya, maka ia akan merasa puas, (b) jika individu siap untuk bertindak, tetapi ia tidak mau melakukannya, maka timbulah rasa ketidakpuasan, (c) jika belum ada kecenderungan bertindak, namun ia dipaksa melakukannya, maka melakukannya akan menjengkelkan, dan (d) jika suatu organisme didukung oleh kesiapan yang kuat untuk memperoleh stimulus maka pelaksanaan tingkah laku akan menimbulkan kepuasan individu sehingga asosiasi cenderung diperkuat. Kesiapan akan dapat kita capai apabila ada harapan, dan usaha dalam bentuk perbuatan yang berulang-ulang hingga mencapai tujuan yang diinginkan yaitu berupa kesuksesan.

Menurut Bandura dkk (Maddox, dkk, 2000, p.277), menjelaskan kesiapan terdiri dari tiga bagian: (a) Emotive Attitudeinal Readiness atau kesiapan sikap dan emosi terdiri dari: (1) kesiapan emosional diasumsikan sebagai tanggung jawab untuk melakukan suatu tugas; (2) antusiasme terhadap suatu tugas, (3) kemauan beradaptasi dengan tugas sewaktu-waktu, (4) kenyamanan dan kemandirian dalam menjalankan tugas, dan (5) mengapresiasi nilai intrinsik dalam suatu tugas, (b) Cognitive Readiness atau kesiapan kognitif terdiri dari: (1) memiliki keterampilan kognitif dan berpikir kritis yang penting untuk melakukan tugasnya, (2) sadar akan kekuatan dan kekurangan, (3) sudah membuat hubungan antara tugas yang dilakukan dengan kenyataan di lapangan, (4) sadar akan nilai diri dan kemauan untuk menjalankan tugas, dan (5) mampu mengintegrasikan konsep-konsep dan alat-alat dari berbagai disiplin keilmuan, (c) Behavioral Readiness atau kesiapan perilaku terdiri dari: (1) bersedia menjalankan fungsi kemitraan dengan rekan-rekan mereka dalam bekerja dan fasilitator, dan (2) mahir mengatur waktu untuk mencapai tujuan yang sesuai dengan tugasnya.

Kesiapan guru sangat penting karena dalam tujuan Kurikulum 2013, diantaranya mendorong peserta didik mampu lebih baik dalam melakukan observasi, bertanya, bernalar, dan mengkomunikasika-mempresentasikan, apa yang mereka peroleh setelah menerima materi pembelajaran.

Kemdikbud (2013, p.9) menjelaskan pembelajaran tematik-integratif merupakan pendekatan pembelajaran yang mengintegrasikan berbagai kompetensi dari berbagai mata pelajaran ke dalam berbagai tema. Pengintegrasian tersebut dilakukan dalam dua hal, yaitu integrasi sikap, keterampilan, dan pengetahuan dalam proses pembelajaran dan integrasi berbagai konsep dasar yang berkaitan. Pembelajaran tematik-integratif memberikan kesempatan kepada peserta didik untuk menghubungkan pengalaman dan pengetahuan sehingga peserta didik lebih mudah menyelesaikan masalah dan memenuhi kebutuhan mereka akan pengetahuan (Huber \& Hutchings, 2008, p.1).

Kemdikbud (2013, p.9) menjelaskan pembelajaran tematik-integratif merupakan pendekatan pembelajaran yang mengintegrasikan berbagai kompetensi dari berbagai mata pelajaran ke dalam berbagai tema. Pengintegrasian tersebut dilakukan dalam dua hal, yaitu integrasi sikap, keterampilan, dan pengetahuan dalam proses pembelajaran dan integrasi berbagai konsep dasar yang berkaitan. Tema ini menjadi alat pemersatu materi yang beragam dari berbagai mata pelajaran. Pembelajaran tematik dimaknai sebagai pembelajaran yang dirancang dan dikemas berdasarkan tema-tema tertentu dan dalam pembahasannya tema-tema ditinjau dari berbagai mata pelajaran.

Keterampilan-keterampilan belajar menurut Fogarty (1991, p.77) meliputi keterampilan berpikir (tinking skill), keterampilan sosial 
(social skill) dan keterampilan mengorganisir (organizing skill). Fogarty (1991, p.xv) menyebutkan ada 10 model pembelajaran terpadu yang terintegrasi antara lain: (1) fragmented; (2) connected; (3) nested; (4) sequenced; (5) shared; (6) webbed; (7) threaded; (8) integrated; (9) immersed; dan (10) networked. Selanjutnya, Fogarty (1991, p.76) menambahkan:

The integrated curricular model represents a cross displinary approach similar to the shared model. The integrated model blends the four major disciplines by setting curricular priorities in each and finding the overlapping skills, concepts, and attitude in all four.

Model ini merupakan pembelajaran terpadu yang menggunakan pendekatan antar bidang studi. Model ini diusahakan dengan cara menggabungkan bidang studi dengan cara menetapkan prioritas kurikuler dan menemukan keterampilan, konsep, dan sikap yang saling tumpang tindih di dalam beberapa bidang studi. Pada model ini tema yang berkaitan dan tumpang tindih merupakan hal terakhir yang ingin dicari dan dipilih oleh guru dalam tahap perencanaan program. Pertama kali guru harus menyeleksi konsep-konsep, keterampilan dan sikap yang diajarkan dari beberapa bidang studi, selanjutnya dipilih beberapa konsep, keterampilan dan sikap yang memiliki keterhubungan yang erat dan tumpang tindih di antara berbagai bidang studi.

Berdasarkan teori yang dikemukakan sebelumnya, kesiapan dalam penelitian ini terdiri dari tiga aspek antara lain: (a) aspek Emotive-Attitudeinal Readines atau kesiapan sikap dan emosi yang dimaksudkan dalam penelitian ini adalah guru bertanggung jawab dalam proses pembelajaran; guru berkeinginan kuat dalam melaksanakan pembelajaran; guru mampu beradaptasi dengan rekan, tugas, lingkungannya; guru mandiri dalam menjalankan tugas, dan mengapresiasi terhadap penerapan pembelajaran melalui penerapan berbagai sumber belajar dan metode yang sesuai dengan Kurikulum 2013, (b) aspek Cognitive Readiness atau kesiapan kognitif yang dimaksudkan dalam penelitian ini adalah guru berpikir kritis yang ditunjukkan mampu membuat peserta didik aktif, kreatif dalam mengembangkan ide, sesuai dengan tingkat kecerdasan dan penalaran peserta didik; guru sadar akan kelebihan dan kekurangan Kurikulum 2013; guru menilai bahwa pembelajaran relevan dengan kondisi di lapangan; guru memiliki kemauan yang ditunjukkan melalui kesadaran diri akan ketidakpahaman Kurikulum 2013; dan guru mampu menggabungkan konsep-konsep dan alat-alat dari berbagai mata pelajaran, dan (c) Aspek Behavioral Readiness atau kesiapan perilaku yang dimaksudkan dalam penelitian ini adalah guru bersedia menjalankan fungsi kemitraan dengan rekan kerja, dan guru mampu mengatur waktu dalam mencapai tujuan yang sesuai dengan tugas.

Berdasarkan uraian tersebut, maka pertanyaan penelitiannya adalah (a) Bagaimana kesiapan guru SD di DIY dalam menerapkan Kurikulum 2013? dan (b) Bagaimana kesiapan guru SD disetiap kabupaten berdasarkan aspek Emotive-Attitudeinal Readiness, Cognitive Readiness dan Behavioral Readiness terhadap penerapan Kurikulum 2013?

\section{Metode Penelitian}

Penelitian ini termasuk jenis penelitian survei yang bertujuan untuk mengetahui kesiapan guru sekolah dasar dalam pelaksanaan pembelajaran tematik-integratif pada Kurikulum 2013. Desain penelitian ini menggunakan pendekatan kuantitatif. Informasi yang terkumpul dapat dijadikan sebagai dasar atau landasan untuk membuat rekomendasi dalam mendukung kebijakan atau keputusan tentang pelaksanaan pembelajaran tematik-integratif.

Penelitian survei ini mengacu pada langkah-langkah penelitian survei yang dikemukakan Rea dan Parker (Sukmadinata, 2010, p.90) sebagai berikut: (1) identification of the focus of the study and method of research, (2) the research schedule and budget, (3) establishment of an information based, (4) the sampling frame, (5) determination of sample size and sampel selection, (6) design of the survey instrument, (7) pretest of survey instrument, (8) selection and training interview, (9) implementation of the survey, (10) codification of the completed questionnaires and computerized data entry, and (11) data analiysis and final report.

Penelitian ini akan dilaksanakan di SD wilayah DIY yang meliputi empat Kabupaten dan satu Kota. Waktu penelitian dilaksanakan mulai bulan Juni 2013 sampai denganbulan Oktober 2013.

Pelaksanaan penelitian kesiapan guru terhadap Kurikulum 2013 ini dilaksanakan dengan jumlah responden sebanyak 182 orang 
guru. Jumlah responden tersebut diambil dari jumlah populasi guru sebanyak 289 orang guru. Populasi penelitian ini adalah guru SD di DIY dan sampel penelitiannya ditentukan menggunakan tabel Krejcie Morgan sebagai berikut.

Tabel 1. Jumlah Populasi dan Sampel SD Setiap Kabupaten

\begin{tabular}{ccc}
\hline Kabupaten & $\begin{array}{c}\text { Populasi } \\
\text { Guru SD }\end{array}$ & $\begin{array}{c}\text { Sampel } \\
\text { Guru SD }\end{array}$ \\
\hline KotaYogyakarta & 102 & 48 \\
Sleman & 54 & 34 \\
Bantul & 66 & 48 \\
Kulonprogo & 23 & 16 \\
Gunungkidul & 43 & 36 \\
Total & 289 & 182 \\
\hline
\end{tabular}

Teknik pengumpulan data yang digunakan dalam penelitian ini adalah angket yang berupa angket tertutup dan angket terbuka. Pemilihan angket sebagai alat pengumpul data dalam penelitian ini didasarkan pada pendapat Sugiyono yang menyatakan bahwa, angket merupakan teknik pengumpul data yang efisien bila peneliti tahu dengan pasti variabel yang akan diukur dan tahu apa yang bisa diharapkan dari responden. Lebih lanjut angket juga cocok digunakan bila jumlah responden cukup besar dan tersebar di wilayah yang luas. Peneliti menggunakan teknik angket terbuka karena dirasa perlu sebagai instrumen pendukung terhadap angket tertutup. Angket terbuka digunakan sebagai teknik pengumpulan data untuk penguatan data yang dikumpulkan melalui angket tertutup.

Dari hasil angket yang diperoleh akan dilakukan skoring dengan rentang 1-4. Instrumen pengumpulan data dalam penelitian ini adalah lembar angket dan pedoman wawancara dengan kisi-kisi sebagai berikut.

Tabel 2. Kisi-Kisi Angket Kesiapan Guru Sekolah Dasar

\begin{tabular}{|c|c|c|c|c|}
\hline $\mathbf{N}$ & \multirow{2}{*}{ Sub Variabel } & \multirow{2}{*}{ Indikator } & \multicolumn{2}{|c|}{ Butir } \\
\hline No & & & Positif (+) & Negatif (-) \\
\hline \multirow[t]{5}{*}{1} & Emotive Attitudinal & tanggung jawab & 1,2 & \\
\hline & & antusias & 3 & \\
\hline & & kemauan beradaptasi & 4 & \\
\hline & & kemandirian & 5 & \\
\hline & & mengapresiasi nilai instrinsik dalam suatu tugas & 6 & \\
\hline \multirow[t]{5}{*}{2} & Cognitive Readines & berpikir kritis & 7 & \\
\hline & & sadar akan kekurangan dan kelebihan & 8 & 9 \\
\hline & & berpikir secara kontekstual & 10 & \\
\hline & & sadar akan nilai diri dan kemauan & 11 & \\
\hline & & mampu mengintegrasikan berbagai disiplin keilmuan & 12 & \\
\hline \multirow[t]{3}{*}{3.} & Behavioral Readines & menjalankan fungsi kemitraan & 13,14 & \\
\hline & & mahir mengatur waktu & 15 & \\
\hline & & Jumlah & \multicolumn{2}{|c|}{15} \\
\hline
\end{tabular}

Teknik analisis data yang digunakan dalam penelitian ini adalah menggunakan teknik presentase. Purwanto (2008, p.219) menyatakan bahwa presentase nilai jawaban responden didapat melalui Rumus:

$$
\frac{\text { Nillai Skar Harapan }}{\text { Nilai Harapan }} \times 100 \%
$$

Hasil presentase, kemudian dikategorikan menjadi empat kategori sebagai berikut.

Tabel 3. Interpretasi Secara Kualitatif dari Persentase

\begin{tabular}{cc}
\hline Persentase & Kategori \\
\hline $76 \%<\mathrm{x} \leq 100 \%$ & Sangat siap \\
$51 \%<\mathrm{x} \leq 76 \%$ & Siap \\
$26 \%<\mathrm{x} \leq 51 \%$ & Kurang Siap \\
$0 \% \leq \mathrm{x} \leq 26 \%$ & Tidak siap \\
\hline
\end{tabular}

\section{Hasil Penelitian}

Hasil penelitian tentang kesiapan guru dalam melaksanakan pembelajaran tematikintegrtif pada Kurikulum 2013 di Daerah Istimewa Yogyakarta adalah sebagai berikut.

Tabel 4. Persentase Kesiapan Guru di Daerah IstimewaYogyakarta

\begin{tabular}{lccc}
\hline $\begin{array}{c}\text { Nama } \\
\text { Kabupaten }\end{array}$ & $\begin{array}{c}\text { Nilai Skor } \\
\text { Jawaban }\end{array}$ & $\begin{array}{c}\text { Persen } \\
(\boldsymbol{\%})\end{array}$ & Kategori \\
\hline Sleman & 1553 & $76,13 \%$ & Sangat siap \\
Yogyakarta & 2267 & $78,72 \%$ & Sangat siap \\
Bantul & 2107 & $73,16 \%$ & Siap \\
Gunungkidul & 1677 & $75,54 \%$ & Siap \\
Kulon Progo & 724 & $75,42 \%$ & Siap \\
Total & 8328 & $75,85 \%$ & Siap \\
\hline
\end{tabular}


Berdasarkan Tabel 4 tersebut, diperoleh hasil persentase kesiapan guru sekolah dasar dalam pelaksanaan pembelajaran tematikintegratif pada Kurikulum 2013 di Kabupaten Bantul, Kabupaten Gunungkidul, dan Kabupaten Kulon Progo berada pada rentang 50\%-75\% yang berarti siap, sedangkan Kabupaten Sleman dan Kota Yogyakarta berada pada rentang $76 \%$ $100 \%$ yang berarti sangat siap. Secara keseluruhan kesiapan guru di Daerah Istimewa Yogyakarta adalah siap. Hal ini berdasarkan hasil persentase kesiapan guru sebesar $75,85 \%$ yang berarti siap.

Kesiapan guru berdasarkan setiap aspek kesiapan yang ada di wilayah Daerah Istimewa Yogyakarta adalah sebaga berikut.

Tabel 5. Persentase Setiap Aspek Kesiapan di Daerah Istimewa Yogyakarta

\begin{tabular}{|c|c|c|c|}
\hline Kriteria & $\begin{array}{c}\text { Nilai Skor } \\
\text { Jawaban }\end{array}$ & $\begin{array}{c}\text { Prosentase } \\
(\%)\end{array}$ & Kategori \\
\hline Emotive & 3443 & 78,392 & $\begin{array}{l}\text { Sangat } \\
\text { siap }\end{array}$ \\
\hline Cognitive & 3126 & 71,175 & Siap \\
\hline $\begin{array}{c}\text { Behaviora } \\
l\end{array}$ & 1759 & 80,100 & $\begin{array}{l}\text { Sangat } \\
\text { siap }\end{array}$ \\
\hline Total & 8328 & 75,847 & Siap \\
\hline
\end{tabular}

Persentase kesiapan guru sekolah dasar dalam pelaksanaan pembelajaran tematikintegratif pada Kurikulum 2013 berdasarkan dari aspek yang menjadi perhatian peneliti, aspek Behavioral Readiness merupakan aspek yang memiliki persentase terbesar yaitu 80,10\%, sedang aspek Emotive-Ettitudinal sebesar 78,39\% dan aspek Cognitive Readiness sebesar 71,18\%. Artinya, dari aspek Behavioral Readiness dan Emotive-Ettitudinal kesiapan guru dalam melaksanakan pembelajaran tematikintegratif termasuk kategori sangat siap, sedangkan dari aspek Cognitive Readiness termasuk kategori siap. Namun, persentase secara keseluruhan dari ketiga aspek termasuk pada kategori siap yaitu sebesar 75,85\%.

Persentase dari aspek Emotive-Ettitudinal di Kota Yogyakarta merupakan persentase terbesar yaitu $80,75 \%$, diikuti oleh Kabupaten Sleman dan Kulon Progo sebesar 79,17\%, Kabupaten Gunungkidul 77,93\% dan Kabupaten Bantul 75\%. Tingginya persentase pada Kota Yogyakarta pada aspek tersebut dikarenakan adanya tanggung jawab, antusiasme, kemauan beradaptasi dan kemandirian yang tinggi pada guru-guru dan sekolah dasar selain itu didukung dengan adanya sarana dan prasarana yang memadai. Persentase terbesar dari aspek $\mathrm{Cog}$ nitive Readiness yaitu di Kota Yogyakarta sebesar 73,78\%, sedangkan untuk Kabupaten Sleman sebesar 71,69\%, Kabupaten Gunungkidul sebesar 70,27\%, Kabupaten Kulon Progo sebesar 69,53\% dan Kabupaten Bantul sebesar $69,44 \%$. Kemampuan dan pemahaman guru dalam pembelajaran tematik-integratif, sadar akan nilai diri dan kemauan, kemampuan mengintegrasikan berbagai disiplin ilmu dan pola pikir kontekstual yang tinggi menjadikan guru-guru sekolah dasar di Kota Yogyakarta siap untuk melaksanakan pembelajaran tematikintegratif sehingga persentase yang diperoleh juga terbesar. Sama halnya dengan aspek Emotive-Ettitudinal dan Cognitive Readiness, pada aspek Behavioral Readiness perolehan persentase terbesar pada Kota Yogyakarta yaitu sebesar 84,55\%, sedangkan Kabupaten Gunungkidul sebesar 81,31\%, Kabupaten Kulon Progo 79,69\%, Kabupaten Sleman 78,92\% dan Kabupaten Bantul 75,69\%. Tingginya persentase Kota Yogyakarta pada aspek Behavioral Readiness dikarenakan berjalannya fungsi kemitraan dengan baik pada sekolah maupun guru, yaitu antarguru selalu melakukan evaluasi terhadap proses pembelajaran yang telah dilaksanakan, melakukan diskusi antarguru, melakukan refleksi dan keteraturan dalam mengatur waktu yang tersedia.

Persentase kesiapan guru sekolah dasar dalam pelaksanaan pembelajaran tematikintegratif pada kurikulum 2013 secara umumdi setiap kabupaten diperoleh hasil persentase sebagai berikut: Sleman 76,13\% (sangat siap), Yogyakarta 78,72\% (sangat siap), Bantul $73,16 \%$ (siap), Gunungkidul 75,54\% (siap), dan Kulon Progo 75,42\% (siap). Secara keseluruhan kesiapan guru di Daerah Istimewa Yogyakarta adalah siap. Hal ini berdasarkan hasil persentase kesiapan guru sebesar $75,85 \%$ yang berarti siap.

Kesiapan guru dalam melaksanakan Kurikulum 2013 juga didukung dari hasil angket terbuka yang diberikan pada guru dari segi kesiapan Emotive-Ettitudinal, Cognitive Readiness dan Behavioral Readiness. Hasil dari segi kesiapan Emotive-Ettitudinal adalah: (a) guru bertanggung jawab dalam melaksanakan Kurikulum 2013; (b) antusiasme mencari informasi mengenai pelaksanaan pembelajaran dengan cara mengikuti sosialisasi, pelatihan, diklat, dan membaca buku pegangan; (c) mau beradaptasi dengan Kurikulum 2013; (d) berusaha mandiri, dan (e) mengapresiasi nilai instrinsik 
dalam suatu tugas melalui penerapan berbagai sumber belajar dan metode yang sesuai dengan Kurikulum 2013.

Hasil analisis angket terbuka dari segi kesiapan Cognitive Readiness adalah (a) guru menilai bahwa pembelajaran tematik-integratif sudah tepat untuk anak sekolah dasar; (b) guru sadar akan kekurangan Kurikulum 2013; (c) guru sadar akan kelebihan Kurikulum 2013; (d) pelaksanaan pembelajaran sudah disesuaikan dengan lingkungan, budaya, sosial sekitar; (e) sadar akan nilai diri dan kemauan ditunjukan melalui kesadaran diri akan ketidakpahaman terhadap Kurikulum 2013, dan (f) mampu mengintegrasikan berbagai disiplin keilmuan.

Hasil analisis angket terbuka dari segi

kesiapan Behavioral Readiness adalah (a) kesiapan menjalankan kemitraan dengan teman sejawat dan (b) mahir mengatur waktu dalam melaksanakan Kurikulum 2013. Hoover (1990) menyatakan bahwa ada lima tahap dalam mengimplementasikan kurikulum yaitu: menentukan kebutuhan untuk adaptasi kurikulum, mengidentifikasi elemen-elemen yang diminta dalam beradaptasi, memilih teknik mengajar dan manajemen perilaku, mengimplementasikan kurikulum, dan memonitor perkembangan adaptasi yang dilakukan. Berdasarkan hasil penelitian yang diperoleh tentang kesiapan guru dalam menerapkan kurikulum 2013, guru sudah melaksanakan beberapa tahap dalam mengimplementasikan kurikulum menurut Hoover. Tahaptahap yang sudah dilaksanakan guru adalah menentukan kebutuhan untuk adaptasi kurikulum, mengidentifikasi elemen-elemen yang diminta dalam beradaptasi, memilih teknik mengajar dan manajemen perilaku. Hal ini ditunjukan dengan kesiapan emotive-ettitudinal yaitu pada aspek kemauan beradaptasi. Berdasarkan hasil penelitian di atas aspek kemauan beradaptasi dinyatakan sangat siap dengan persentase sebesar 79,05\%.

\section{Simpulan}

Berdasarkan hasil penelitian yang dilakukan di Daerah Istimewa Yogyakarta tentang kesiapan guru sekolah dasar dalam melaksanakan pembelajaran tematik-integratif sesuai dengan Kurikulum 2013, dapat disimpulkan bahwa: (1) kesiapan guru SD di DIY dalam menerapkan pembelajaran tematik-integratif sudah siap $(75,847 \%)$. Tingkat kesiapan guru yang paling tinggi berada di Kota Yogyakarta, dan tingkat kesiapan guru yang paling rendah berada di kabupaten Bantul, dan (2) kesiapan guru jika dilihat dari setiap aspek kesiapan adalah sebagai berikut: (a) kesiapan guru dari aspek Emotive-Ettitudinal di masing-masing kabupaten dan kota di Daerah Istimewa Yogyakarta adalah 80,75\% di Kota Yogyakarta, 79,17\% di Kabupaten Sleman dan Kulon Progo, 77,93\% di Kabupaten Gunungkidul, dan 75\% Kabupaten Bantul di Kabupaten Bantul. Berdasarkan presentase tersebut kesiapan guru dari aspek Emotive-Ettitudinal di Kota Yogyakarta, Kabupaten Sleman, Kabupaten Kulon Progo, dan Kabupaten Gunungkidul pada kategori sangat siap dan di Kabupaten Bantul pada kategori siap; (b) kesiapan guru dari aspek Cognitive Readiness yaitu di Kota Yogyakarta sebesar 73,78\%, sedangkan untuk Kabupaten Sleman sebesar 71,69\%, Kabupaten Gunungkidul sebesar 70,27\%, Kabupaten Kulon Progo sebesar 69,53\% dan Kabupaten Bantul sebesar $69,44 \%$. Berdasarkan presentase tersebut kesiapan dari aspek Cognitive Readiness pada masing-masing kabupaten berada pada kategori siap, dan (c) kesiapan dari aspek Behavioral Readiness perolehan persentase terbesar pada Kota Yogyakarta yaitu sebesar $84,55 \%$, sedangkan Kabupaten Gunungkidul sebesar 81,31\%, Kabupaten Kulon Progo 79,69\%, Kabupaten Sleman 78,92\% dan Kabupaten Bantul 75,69\%. Berdasarkan presentase tersebut kesiapan guru dari aspek Behavioral Readiness di Kota Yogyakarta, Kabupaten Sleman, Kabupaten Kulon Progo, dan Kabupaten Gunungkidul pada kategori sangat siap dan di Kabupaten Bantul pada kategori siap. Tetapi kesiapan guru ini bukan berarti guru tidak memerlukan bantuan apapun. Pada pertanyaan dalam angket nomor 5, mengenai kebutuhan guru dalam bantuan dan pendampingan dalam melaksanakan Kurikulum 2013 sebagian besar guru menjawab masih membutuhkan bantuan dan pendampingan.

\section{Daftar Pustaka}

Arifin, Zaenal. (2010). Evaluasi pembelajaran. Bandung: PT. Remaja Rosda Karya

Danim, S. (2010). Perkembangan peserta didik. Bandung: Alfabeta

Depdiknas. (2006). Strategi pembelajaran yang mengaktifkan siswa. Jakarta: Depdiknas.

Depdiknas. (2000). Kamus besar bahasa indonesia. Edisi Ketiga. Jakarta: Balai Pustaka. 
Feldman, S.R. (2012). Discovering the life span. USA: Pearson Prentice Hall.

Fogarty, R. (1991). How to integrate the curricula. Palatine: Skylight Publising Inc.

Hoover, J.J. (1990). Curriculum adaption: a five-step process for classroom implementation. Journal of Intervention in School and Clinic Vol 25:407.

Huber \& Hutchings. (2008). Integrative Learning: Mapping The Terrain International. Journal for The Scholarship of Teaching \& Learning Vol.2 No.1.

Irianto, Y B. (2011). Kebijakan pembaruan pendidikan. Jakarta: Rajawali Pers

Kemdikbud. (2013). Kompetensi Dasar SD/MI Versi Maret 1.

Kerlinger, F.N. (2006). Asas-asas penelitian behavioral edisi ketiga. Yogyakarta: Gadjah Mada University Press.

Kon Chon Min, dkk. (2012). Teachers' Understanding and Practice towards Thematic Approach in Teaching Integrated Living Skills (ILS) in Malaysia. International Journal of Humanities and Social Science. Vol. 2 No. 23 December 2012.

Kyriacou, C. (2009). Effective teaching in school (theory and practice). United Kingdom: Nelson Thornes.
Mardapi, Djemari. (2007). Teknik penyusunan instrumen tes dan nontes. Yogyakarta: Mitra Cendikia.

Nazir, M. (2005). Metode penelitian. Bogor: Ghalia Indonesia.

Maddox, N. et. all. (2000). Learning Readiness: An Underappreciated Yet Vital Dimension In Experiential Learning. Jornal of Developments in Business Simulation \& Experiential Learning.

Sisdiknas. (2012). Uji Publik Kurikulum 2013: Penyederhanaan, TematikIntegratif.http://www.kemdiknas.go.id/ kemdikbud/uji-publik-kurikulum-20131. Diakses pada tanggal 10/03/2013 pukul 09.00 WIB.

Sugiyono. (2008). Metode penelitian pendidikan: pendekatan kuantitatif, kualitatif, dan $R \& D$. Bandung: Alfabeta.

Sukandi. (2003). Belajar aktif dan terpadu. Surabaya: Duta Graha Pustaka.

Sukmadinata, N.S. (2010). Metode penelitian. Bandung: Remaja Rosdakarya.

Tim Pustaka Yustisia. (2007). Panduan lengkap KTSP. Yogyakarta: Pustaka Yustisia.

Trianto. (2010). Model pembelajaran terpadu: konsep, landasan, dan implementasinya pada kurikulum tingkat satuan pendidikan (KTSP). Jakarta: Bumi Aksara.

Trianto. (2012). Model pembelajaran terpadu. Jakarta: Bumi Aksara. 